\title{
Stefano Chemelli, Le Tenebre del crimine: uno sguardo alla "Commedia Umana" di Honoré de Balzac
}

\section{Marco Stupazzoni}

\section{(2) OpenEdition}

1 Journals

\section{Edizione digitale}

URL: http://journals.openedition.org/studifrancesi/1553

DOI: 10.4000/studifrancesi. 1553

ISSN: 2421-5856

\section{Editore}

Rosenberg \& Sellier

\section{Edizione cartacea}

Data di pubblicazione: 1 novembre 2014

Paginazione: 618

ISSN: 0039-2944

\section{Notizia bibliografica digitale}

Marco Stupazzoni, «Stefano Chemelli, Le Tenebre del crimine: uno sguardo alla "Commedia Umana" di Honoré de Balzac ", Studi Francesi [Online], 174 (LVIII | III) | 2014, online dal 01 novembre 2014, consultato il 18 septembre 2020. URL : http://journals.openedition.org/studifrancesi/1553 ; DOI : https://doi.org/10.4000/studifrancesi.1553

Questo documento è stato generato automaticamente il 18 settembre 2020.

\section{(c) 9 (i) $\Theta$}

Studi Francesi è distribuita con Licenza Creative Commons Attribuzione - Non commerciale - Non opere derivate 4.0 Internazionale. 


\title{
Stefano Chemelli, Le Tenebre del crimine: uno sguardo alla "Commedia Umana" di Honoré de Balzac
}

\author{
Marco Stupazzoni
}

\section{NOTIZIA}

STEFANO CHEMELli, Le Tenebre del crimine: uno sguardo alla "Commedia Umana" di Honoré de Balzac, «Altre Storie», Trento, Fondazione Museo storico del Trentino, anno XV, n. 41, maggio /agosto 2013, pp. 11-12.

1 In questo breve contributo, l'autore analizza, assumendo come punto di riferimento iniziale del suo articolo il romanzo Une Ténébreuse Affaire, le tecniche di rappresentazione del crimine in Balzac e, in particolar modo, la pregnanza descrittiva ed argomentativa del dettaglio come elemento di potente penetrazione introspettiva oltre che di indagine e di ricostruzione storico-sociale. Al lettore, Balzac «dona una parola che colpisce» ed apre «mondi inesplorati» e segreti che si svelano attraverso «una scrittura indomabile, onnicomprensiva» che «dura nel tempo, rimane tra noi, senza tradire la sua origine» (p. 11). Attraverso, ad esempio, la figura di Vautrin, Balzac ci fa comprendere i significati e gli stili di un mondo opaco e dissoluto, quello della criminalità, inteso come un "continuo limite oltre il quale siamo indotti invariabilmente a misurare e soppesare le maschere infinite del teatro del mondo» (ibid.). 